\title{
Coastal Fishermen's Quality of Life in Kuala Dungun: A Study of Income and Household Expenditure
}

Zuriyati Ahmad, Nik Noor Afizah Azlan, Wan Maziah Wan Ab Razak, Ahmad Suffian Mohd Zahari, Baharom Abdul Rahman, Ramli Ibrahim Tinik

To Link this Article: http://dx.doi.org/10.6007/IJARBSS/v11-i18/11627 DOI:10.6007/IJARBSS/v11-i18/11627

Received: 12 August 2021, Revised: 16 September 2021, Accepted: 29 September 2021

Published Online: 22 October 2021

In-Text Citation: (Ahmad et al., 2021)

To Cite this Article: Ahmad, Z., Azlan, N. N. A., Razak, W. M. W. A., Zahari, A. S. M., Rahman, B. A., \& Tinik, R. I. (2021). Coastal Fishermen's Quality of Life in Kuala Dungun: A Study of Income and Household Expenditure. International Journal of Academic Research in Business and Social Sciences, 11(18), 191-201.

Copyright: (C) 2021 The Author(s)

Published by Human Resource Management Academic Research Society (www.hrmars.com)

This article is published under the Creative Commons Attribution (CC BY 4.0) license. Anyone may reproduce, distribute, translate and create derivative works of this article (for both commercial and non-commercial purposes), subject to full attribution to the original publication and authors. The full terms of this license may be seen

at: http://creativecommons.org/licences/by/4.0/legalcode

Special Issue Title: TiBECVII 2021, 2021, Pg. 191 - 201

Full Terms \& Conditions of access and use can be found at http://hrmars.com/index.php/pages/detail/publication-ethics 


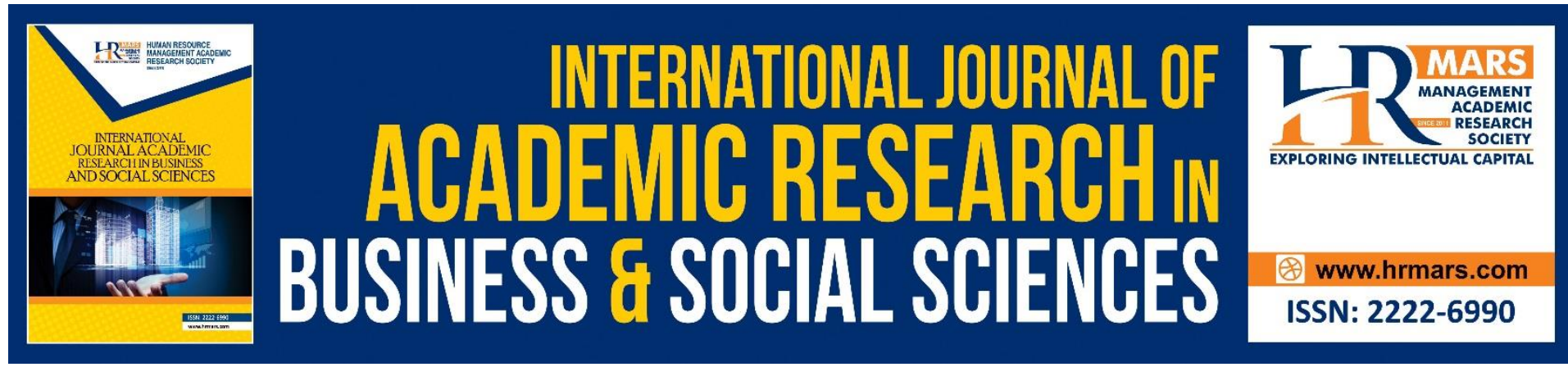

\title{
Coastal Fishermen's Quality of Life in Kuala Dungun: A Study of Income and Household Expenditure
}

\author{
Zuriyati Ahmad ${ }^{1}$, Nik Noor Afizah Azlan², Wan Maziah Wan Ab \\ Razak $^{3}$, Ahmad Suffian Mohd Zahari ${ }^{4}$ Baharom Abdul \\ Rahman ${ }^{5}$, Ramli Ibrahim Tinik ${ }^{6}$ \\ 1,2,3,4,5 Faculty of Business and Management, Universiti Teknologi MARA Cawangan \\ Terengganu, Malaysia, ${ }^{6}$ Faculty of Economics and Business, Universitas Sumatera Utara, \\ Medan, Indonesia \\ Corresponding email: nikno561@uitm.edu.my
}

\begin{abstract}
This descriptive study aims at understanding the different aspects of the lives of fishermen. A preliminary study to gauge the household income and expenditure among fishermen in Kuala Dungun, Terengganu was undertaken in early 2020 through the use of interviews and a self-developed questionnaire. Respondents, ranging from different levels of the fishery profession were requested to complete a questionnaire which requires them to reveal their income and household expenditure. The findings of the study revealed the grim challenges faced by the fishermen in balancing their income and household expenditure. In the absence of any additional source of income, let alone savings, the fishermen relied their sustenance on their fishing activities to support their family. The average income earned by the respondents are below the poverty line while the majority of them recorded a much higher household expenditure than their income. Family size and higher living standards have continuously caught the fishermen in the web of debt and poverty, without any relief in sight. The study suggested that education can be used as an indicator of an individual's capabilities to manage life, thus lacking thereof, as is the case of the surveyed respondents, deprive them from being able to effectively fight poverty and improve their living conditions.
\end{abstract}

Keywords: Quality of Life, Fishermen, Household Expenditure, Income, Poverty

\section{Introduction}

Fishery is an important economic and social activity that people have practiced since prehistoric times, wherever access to water is available. Many studies have shown that most coastal fishing communities are poor and found to be living with an unsatisfactory level of poverty. The fishing industry contributes $0.9 \%$ of the nation's Gross Domestic Product (GDP) in 2019 (FOA, 2020). Although this is considered small, the fisheries sector is a major producer of protein for the population of this country. The government thus introduced many initiatives to eradicate poverty among the poor, particularly in the fishing community. One 
such initiative is to provide better opportunities for the fishermen communities, including better social amenities. Other programs initiated then, include low-cost housing scheme, electricity and piped water, health services and education. The Department of Fisheries Malaysia under the Fisheries Development Authority of Malaysia (LKIM) has been given the responsibility to monitor and assist the affairs and welfare of the nation's fishermen and consequently increasing the quality of life.

The scope and aspects of quality of life is boundless. This includes how to measure "the goodness" of someone from various aspects of life including the emotional reaction to events, dispositions, fulfilling and satisfying life, taste, and the satisfaction of job and personal relationships (Rezahan, et. al., 2018). Many writers and researchers discussed the concept of quality or well-being. For example, Renwick (2006) stated that the well-being of life is something that makes a person feel fun, happy and feel his life is meaningful. Muhamad Fadhil (2003) also highlighted well-being is in fact an attempt to solve problems and improve the quality of human life so that it is in a state of living safe, healthy and comfortable both physically, socially and psychologically. While, Norizan et. al (2017) divided the well-being of life into two quality categories, i.e., objective quality of life and subjective quality of life. The objective quality of life means the necessities of life can be enjoyed by the individual and can be seen externally such as income, housing, health and education. The subjective quality of life is the satisfaction and enjoyment of life that is felt by individuals such as feeling fun and grateful for having a job well, successful children and having a happy family. He further explains the well-being of life is a subjective quality of life because that well-being is the culmination of human satisfaction and goodness. Abdul Rahman (2005) explains the concept of well-being or quality of life not merely measured by material values such as home ownership, vehicles, high level of education but it also covers aspects which is immaterial such as feelings of affection, warmth, compassion pity between individuals and always openhearted.

Many factors have been identified by various researchers to constitute good quality of life. Past studies also showed that the education indicator is among the determinants of improving the fishermen's quality of life. In fact, Malaysian Quality of income or distribution, environment, transport and communication, health, education, housing, environment, family life, social participation, public safety and culture and entertainment to the group of fishermen. Income distribution is one of the major elements in quality of life. Local fishery in Malaysia is still dominated by small-scale, simple technology, highly influenced by rhythm seasons, and its products are limited only for local consumption. Efforts to improve traditional fishermen household's welfare require approaches that pay attention to household decision making pattern (Purwanti, 2010). The income earned by fishermen through their fish productions are subjected to the seasonal factors, size of boats and equipment. Fishermen earned income will be allocated to meet all primary and secondary needs, both food and nonfood consumption (Rachman, et al., 2006). Their income sometimes is insufficient for the necessities therefore will likely to become problems and affect the quality of life. Therefore, the government's role is seen as an effort to help the fishermen and farmers as well as livestock farmers to be competitive with the other sectors, thus helping them to increase their household income and living standards. In addition to this, the current development in tourism and industrial sectors have largely contributed to the improved quality of life for the nation's fishing communities. 


\section{Problem Statement}

60 percent of the world's population has made fishery sources as their daily protein (Ali, 2007). Nevertheless, fishermen are considered to be in the poor category among Asia's population. This community is considered as one of the most vulnerable social groups in many countries (Bravo-Olivas et al., 2015). Although fishing activities may not contribute significantly to gross national products, for a large number of coastal inhabitants, fishing is the only activity to develop a local economy. Based on the previous studies (Azril et al., 2013; Jalihah et al., 2014; Edwin et al., 2018; Putrawan \& Ananda, 2019), fishermen are found to be living in poverty and experiencing low quality of life. Basically, employment as fishermen is a weather-dependent job. Fishermen will only go out for sustenance if the weather is good, otherwise they will spend most of their time on land. For the fishermen in the east coast region of Malaysia, work will be stunted for several months during the monsoon season. As such, their income will be severely affected, thus causing a gruesome effect on their living conditions and their ability to fulfil the family's basic needs.

Although the fisheries sector has undergone major changes in terms of technology and number of landings, relatively, the economic status of most of the fishing communities is also still at a low level (Samir \& Sara, 2012). Maru et al (2018) claimed that the living conditions of fishermen do not correlate with their role in enhancing productivity of the local community. The same factor could also impend the government's target of providing $20 \%$ of fisheries products for the nation food supply through the National Agrofood Policy (NAP 2011-2020). Perhaps it could be concluded that our fishermen's current quality of life may have a significant effect on their productivity in the form of fisheries outputs.

This study tries to apply the MWI 2013 by the Economic Planning Unit of the Prime Minister of Malaysia Department, as a basis for identifying the elements of quality of life. These elements include income or distribution, environment, transport and communication, health, education, housing, environment, family life, social participation, public safety and culture and entertainment to the group of fishermen in east the coast of Malaysian peninsula. However, the preliminary investigation will only focus on two major elements of quality of life, which is income and household expenditure among fishermen in Kuala Dungun, Terengganu.

\section{Literature Review}

Substantial literature in the area of the quality of life focusing on income and expenditure pattern has been found in earlier works. In the case of Indonesia for example, Muhammad et al. (2015); Edwin et al (2018); Alberto et al (2018); Rusdiana et al (2020) are among researchers on income pattern of fishermen's quality of life. Muhammad et al (2015) for example highlighted the roles and responsibilities of the government to improve living conditions through increased income. Their study investigates the living standards of fishermen in North Konawe district. The study identified several reasons for the poor living conditions of the fishermen, namely lack of education, the productivity of fishing is highly dependent on the season, limited working capital, lack of supporting facilities, poor market mechanism, the length of the transfer technology and poor living conditions. In support of Muhammad et al (2015); Alberto et al (2018) stated that the goal of the government is to promote prosperity within the community through better care and support for the welfare of the fishermen's living conditions. The goal can only be realized if there is an improvement in 
the level of income among fishermen. On the hand, Edwin et al., (2018) conducted interviews, observations and focus group discussions in North Sulawesi regency. Cost of living among costal fishermen has been focused in the study. It is found that the fishermen have to bear higher cost of living with minimal income. The lack of such basic knowledge had deprived them of the opportunity to venture into a more sophisticated fishing technologies, thus landing them in jobs no higher than crew members. The fishermen spent their entire life living on incomes as crew members, which caused them to live beyond the poverty levels.

Studying on the income and consumption pattern in West Java, Rusdiana et al (2020) found that the income and the lifestyle of expenditure is dependent on nature where in certain seasons fishermen's income will grow very high but in the following seasons, fishermen's income will decrease or even will be not existent. A survey was conducted and it is found that the income and number of family members influence the consumption patterns of fishermen households. It also can be concluded that there is a positive and significant impact between social economic status income and number of family members on the consumption patterns of fishermen households. Similarly, Wekke and Cahaya (2015) explore the survival strategy by considering the consumption of food by the fishermen's family. The ability of fishermen to meet the minimum basic needs of daily life is found to be very limited. For fishing communities, food is the most important need among the basic necessities of life. In order to survive fishermen needs to borrow money and rice from the neighbours.

Subramaniam and Karuppusamy (2017) explored on the income and expenditure pattern and its impact on socio economic status of marine fish workers in Tamil Naidu. It is found the living conditions of fishermen are still socially and economically backward. Fish workers, particularly in the fishing communities are the most disadvantaged group. They placed in a very low status in the society. From the analyses the result shows that the major sources of incomes are from fish catching followed by land income, livestock income and other sources like salary, rent, business of the fish workers. The study concludes that all the fishermen's expenditure largely spent on education of their children.

In Malaysia, Mohd et al (2006); Lili et al (2019) studied the wellbeing of a coastal fishery community in Terengganu. Mohd et al. (2006) focused on four main aspects of fisherman's profile or attributes, government role, community role and demographic. The study found that a big majority of the fishermen are struggling with their sustenance and living in the rural poor category. In support to Mohd et al (2006); Lili et al (2019) highlighted the local fishermen in Terengganu are facing the poverty and minimal fishing activity due to the environmental and climate issues. These issues have led to a decline in the fishery production and income. This study found that that average income for two fishing areas are USD 626 and USD household income. It reveals that the household income in both areas did not pass the National median household income which was USD 1,307 in 2016. The authors suggested that there should be occupational opportunities fishermen's wife and children can contribute in increasing their household to increase the household income. Abdul Rahim et al (2018) discovered the lack of ownership of livelihood assets such as human assets, physical assets, financial assets, natural assets, and social assets among fishermen households will cause them to remain in the vicious trap of poverty. This situation is further exacerbated when there is an increase in operational costs of fishing and living costs increase due to rising prices of daily necessities. This situation will lead to fishermen to be trapped in a vicious cycle of poverty 
that contributed to the lower quality of life in the fishing community. Besides that, many studies (Ismail, 2013; Nor, 2010; Zaifurin et al., 2009; Cooke, 2008; Wafi et al., 2019) found that the majority of fishermen never went to school or failed to finish school. These grim facts are reinforced with the notion that employment as a fisherman does not require educational qualifications although access to educational facilities in urban areas is available. In addition, the tendency to follow the footsteps of the father as fishermen develops because the children were introduced to the life at sea since they were a child, thus enhancing their belief of becoming fishermen for the rest of their lives. Norizan et al (2017) however suggested factors contributing to the improvement in quality of life among fishermen. The study stated that income, savings, housing, family surroundings and fishing equipment play major contributors to enhance the quality of life among fishermen.

\section{Methodology}

This study was undertaken in early 2020 in a small fishing community in Dungun Terengganu. 31 preliminary questionnaires were distributed randomly to a population of fishermen in addition to interviews with the relevant fisheries officials. Prior to the questionnaire distribution, visits to the relevant authorities such as the leaders of the Fishermen Association and officials of the Fisheries Department were conducted to understand the responsibilities of the respective authorities in handling fishermen welfare. The meeting also requested permission from the authorities to distribute questionnaires to the surrounding fishermen. $A$ survey questionnaire consisting of items requesting respondents' income, household expenditure and other pertinent questions were later distributed among the available fishermen within the compound of the LKIM building and surrounding areas. Experienced and trained enumerators were hired to assist the data collection process and their work was monitored by the research team. The data collection process took two days to complete.

\section{Measurement}

The study focused on items that were divided into four parts, namely, number of family members, monthly income, household income and household expenditure. The items included within the questionnaire are consistent with the objectives of the study. The response options are either open-ended or closed ended. The validity of the developed questionnaire was further strengthened through several discussions among researchers. The discussions focused on rephrasing the items and checked the suitability of the Likert-type scale used as options for answer.

\section{Results Analysis and Discussion}

Fishing is one of the oldest professions known to men, and it has been transcended down from one generation to the other ever since. Good fishermen have been known to rely on muscle and experience to ply the trade and as such education has never been seen as important. Poor education has always been related to poor living condition which eventually lead to poverty. The use of higher fishing technologies and expertise levels demand fishermen with high level of educational background to explore new possibilities and take charge of the fishing industry. Lacking there will only subject them to becoming just crew members forever, thus earning incomes which will barely sustain the needs of the whole family. Figure 1 therefore shows the income and expenditure of fishermen in Kuala Dungun. 


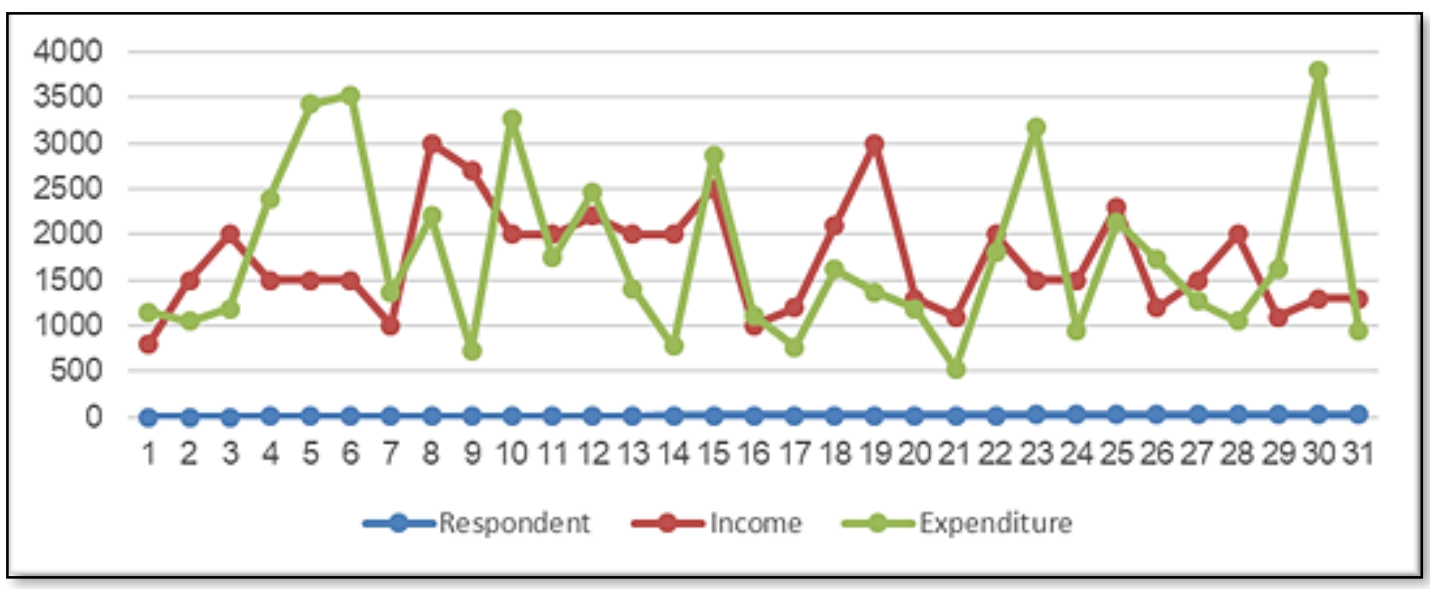

Figure 1: Income and Expenditure of Fishermen

Figure 1 reveals the fact that all fishermen surveyed earned a monthly income ranging from RM800 to RM3000 per month, which is considered below the B40 income category set by the Malaysian government. Household expenditure however, ranges from RM500 to RM4000. The earned income will be allocated to meet the necessities need both food and non-food consumption. However, their expenditure to meet the minimum necessity needs of daily life is found to be very limited. The average income earned by the respondents are below the poverty line while the majority of them recorded a much higher household expenditure than their income. The differential effect between income and expenditure among the fishermen indicated a large gap between them, thus sending the gruesome message of constant debt and hardship.

Table 1: Family Income of Respondents

\begin{tabular}{|l|l|l|l|l|l|l|l|l|l|l|}
\hline Respondent & 1 & 2 & 3 & 4 & 5 & 7 & 8 & 9 & 10 & 11 \\
\hline $\begin{array}{l}\text { No. family } \\
\text { Member }\end{array}$ & 4 & 6 & 6 & 3 & 7 & 5 & 5 & 4 & 7 & 6 \\
\hline $\begin{array}{l}\text { Family (nM) } \\
\text { Income (RM) }\end{array}$ & 800 & 1500 & 2000 & 1500 & 1500 & 1500 & 1000 & 3000 & 2700 & 2000 \\
\hline $\begin{array}{l}\text { Income per } \\
\text { capita (RM) }\end{array}$ & 200 & 250 & 333 & 500 & 214 & 300 & 200 & 750 & 386 & 333 \\
\hline
\end{tabular}

\begin{tabular}{|l|l|l|l|l|l|l|l|l|l|l|}
\hline Respondent & 12 & 13 & 14 & 15 & 16 & 17 & 18 & 19 & 20 & 21 \\
\hline $\begin{array}{l}\text { No. family } \\
\text { Member }\end{array}$ & 4 & 5 & 10 & 4 & 5 & 5 & 5 & 6 & 6 & 5 \\
\hline $\begin{array}{l}\text { Family } \\
\text { Income (RM) }\end{array}$ & 2000 & 2200 & 2000 & 2000 & 2500 & 1000 & 1200 & 2100 & 3000 & 1300 \\
\hline $\begin{array}{l}\text { Income per } \\
\text { capita (RM) }\end{array}$ & 500 & 440 & 200 & 500 & 500 & 200 & 240 & 350 & 500 & 260 \\
\hline
\end{tabular}

\begin{tabular}{|l|l|l|l|l|l|l|l|l|l|l|l|}
\hline Respondent & 22 & 23 & 24 & 25 & 26 & 27 & 28 & 29 & 30 & 31 & 32 \\
\hline $\begin{array}{l}\text { No. family } \\
\text { Member }\end{array}$ & 4 & 6 & 5 & 3 & 5 & 6 & 6 & 5 & 5 & 9 & 4 \\
\hline $\begin{array}{l}\text { Family } \\
\text { Income (RM) }\end{array}$ & 1100 & 2000 & 1500 & 1500 & 2300 & 1200 & 1500 & 2000 & 1100 & 1300 & 1300 \\
\hline
\end{tabular}




\begin{tabular}{|l|l|l|l|l|l|l|l|l|l|l|l|}
\hline $\begin{array}{l}\text { Income per } \\
\text { capita (RM) }\end{array}$ & 275 & 333 & 300 & 500 & 460 & 200 & 250 & 400 & 220 & 144 & 325 \\
\hline
\end{tabular}

*Respondent No. 6 is omitted.

Table 2: Number of Family Members, Income, and Income per capita

\begin{tabular}{|c|c|c|c|}
\hline Criteria & Range & Frequency & $\begin{array}{l}\text { Percentage } \\
\text { (\%) }\end{array}$ \\
\hline \multirow{3}{*}{ Number of Family Members } & $1-4$ & 8 & 25.81 \\
\hline & $5-9$ & 22 & 70.97 \\
\hline & 10 & 1 & 3.22 \\
\hline \multirow{5}{*}{ Family Income } & $\begin{array}{l}\text { RM } 500- \\
\text { RM999 }\end{array}$ & 1 & 3.23 \\
\hline & $\begin{array}{l}\text { RM1000- } \\
\text { RM1499 }\end{array}$ & 9 & 29.03 \\
\hline & $\begin{array}{l}\text { RM1500- } \\
\text { RM1999 }\end{array}$ & 7 & 22.58 \\
\hline & $\begin{array}{l}\text { RM2000- } \\
\text { RM2499 }\end{array}$ & 10 & 32.26 \\
\hline & $>\mathrm{RM} 2500$ & 4 & 12.90 \\
\hline \multirow{5}{*}{ Income per capita } & $\begin{array}{l}\text { RM } 100- \\
\text { RM199 }\end{array}$ & 1 & 3.22 \\
\hline & $\begin{array}{l}\text { RM200- } \\
\text { RM299 }\end{array}$ & 12 & 38.70 \\
\hline & $\begin{array}{l}\text { RM300- } \\
\text { RM399 }\end{array}$ & 7 & 22.58 \\
\hline & $\begin{array}{l}\text { RM400- } \\
\text { RM499 }\end{array}$ & 3 & 9.67 \\
\hline & $>$ RM500 & 7 & 22.58 \\
\hline
\end{tabular}

The family income from the fishing activity is shown in Table 1, majority (32.26\%) of the fishermen earned between RM2000-RM2499. The highest income obtained by fishermen amounted to >RM 2500 while the lowest of RM1000-RM1499 income with $3.22 \%$.

The income per capita from the fishing activity in Table 2, show that most fishermen $(38.70 \%)$ earned between RM200-RM299 with the highest >RM500 (22.58\%), whilst the lowest received RM $100-$ RM199 or 3.22\%. The finding depicts that the bigger the household size, the higher the family consumption. According to the Department of Statistics Malaysia in 2019, the median for Malaysian household income was RM5,873 and therefore did not pass the national median household income with an average of RM200-RM299 and RM300RM399. This finding is in support with previous finding of Lili et al (2019) that the household income in two fishing areas in Terengganu did not pass the National median household income. The average income earned by the respondents are below the poverty line while the majority of them recorded a much higher household expenditure than their income. Family size and higher living standards have continuously caught the fishermen in the web of debt and poverty, without any relief in sight. 
The low income among fishermen is also due to the ownership of fishing equipment that affects income and affect the poor life experienced by fishermen (Karjuni et al., 2018). There is no ownership of the basic equipment of fishing activities such as nets, engines and boats that can affect the livelihood of fishermen. Therefore, the fishermen involved have to divide their income obtained with other fishermen as they boarded the catches with other fishermen. In other words, the source of income of fishermen is not fixed. As a result, this group is very vulnerable to the problem of poverty.

Most of the coastal fishermen rely entirely on fishing industry as their main source of livelihood. The fisheries sector has undergone major changes in terms of technology and number of fish landings, however the economic status of most of the fishing community in the country is still relatively poor. Although there has been an increase in household income of fishermen through government programs and activities, however these improvements do not reflect the socio-economy of the fishing community. At the same time, lack of involvement in doing part time job in other sector activities and lack of ownership of fisherman assets also complicate the situation. Failure to find additional income from other activities will result in fishermen continue to be in the trap of poverty especially during the monsoon season when they are not able to go to the sea. The absence of income during the monsoon season have compounded their debt as they survived on daily loans from their employers and family members to make ends meet especially those with large number of family members. The end of the monsoon season also signals the need for them to find financial sources to repair their fishing gears as well as fishing supplies before they can start earn an income again. Constantly trapped in this web of debt, the fishermen will continuously live in this state of poverty with no end in sight, let alone have any savings for future use. Their income which is insufficient for the necessities therefore will likely to become problems and affect their quality of life.

\section{Conclusions}

After years of research and revelations of finding on the quality of life of fishermen in the country and elsewhere, it seems that nothing much has changed. Perhaps lack of education is also the major contributor to most of the current issues affecting the lives of most of our fishermen. The income of a handyman or a boat crew in a fishing trip can hardly meet the needs of the family, especially when there are many mouths to feed at home. The creative and productive mind, which is always associated with a person's educational background may have been the reason behind the investigated fishermen's lack of motivation and creativity to find additional income, especially during the monsoon season. Absence of income due to the weather, and compounded by their lack of creativity to earn additional income may result in their dependence on personal debts, which will only add salt to their poverty wound.

The findings of this preliminary study only confirm the fact that unless something drastic is done to change the mentality of our fishermen, their lives are doomed to the eternal trap of poverty and debts. Encouraging and providing more opportunities for the children of the fishermen to pursue their education is perhaps a good step in the right direction to stop this vicious poverty cycle that have been plaguing our seamen ever since. Perhaps a new generation of educated fishermen will arise after this; fishermen who will paint a new picture of the fishing profession and be able to contribute more, specifically to the families of the fishermen, and to the nation in general. Besides that, the government's role is seen to be vital 
in helping the fishermen to be competitive with the other sectors, thus helping them to increase their household income and living standards.

\section{References}

Ali, I. (2007). Pembangunan Industri Hiliran Berasaskan Perikanan di Sabah. Penerbit Universiti Malaysia Sabah.

Abdul Rahim, A., Zubir, A. I., Roslina, K., \& Kalthum, H. (2018). Social Safety Nets for Vulnerable and Low Income Group: A Case Study of Fishing Communities in Malaysia. TESSHI eProceedings. https://ir.uitm.edu.my/id/eprint/34907/1/34907.pdf

Abdul Rahman, S. F. (2005). Kriteria Kualiti Hidup Berkeluarga. Utusan Malaysia https://www.ikim.gov.my/new-wp/index.php/2005/05/20/kriteria-kualiti-hidupberkeluarga/

Alberto, A. R., Lein \& Setiawina, N. D. (2018). Factors Affecting the Fishermen Household Income and Welfare. International Research Journal of Management, IT and Social Sciences, 5, 80-90.

Bravo-Olivas, M. L., Chavez, D. R. M., Malcom, C. D., \& Espinoza-Shanchez, R. (2015). Notes on the Quality of Life of Artisinal Small Scale Fisherman Along the Pacific Coast of Jalisco Mexico. Sustainability Journal, 7, 6046-6068.

Cooke, F. M. (2008). The Bajau of Mengkabong: Potential Partners in Wetlands Conservation? Seminar Paper Series Number 5, 2008. Research Unit for Ethnography and Development, School of Social Sciences, Universiti Malaysia Sabah.

Edwin, W., Ery, T. D., Mit, W., \& Hari, W. (2018). Need Analysis of Coastal Fishermen Empowerment Based on Economics Education and Potential Coastal in Minhasa Regency of North Sulawesi. IOP Conference Series Earth and Environmental Science, 156(1).

FAO. (2020). The State of World Fisheries and Aquaculture 2020. Sustainability in action. Rome. https://doi.org/10.4060/ca9229en

Ismail, A. (2013). Nelayan Artisanal di Sabah. Kota Kinabalu: Penerbit Universiti Malaysia Sabah.

Azril, H. M. S., Bahaman, A. S., Jeffrey, L. D., \& Sulaiman, M. Y. (2013). The Process of Social Adaptation Towards Climate Change among Malaysian Fishermen. International Journal of Climate Change Strategies and Management, 5(1), 38-53.

Jalihah, M. D., \& Hafizah, S. (2014). Pengkategorian Nelayan Bandar dan Kemiskinan: Penelitian Terhadap Nelayan di Pulau Gaya, Kota Kinabalu Sabah. https://www.academia.edu/35262796/pengkategoriannelayan. Jurnal Kinabalu.pdf

Karjuni, D. M., Aldri, F., \& Hidayatul, F. (2018). Fisherman Empowerment and Poverty in Pesisir Selatan regency. MATEC Web of Conferences, 229.

Lili, M. Z., Alfian, Z., Mohd, H. I., \& Wan, L. (2019). Socio-economic Profile Comparison of Fishermen Community in Kuala Marang and Seberang Takir, Terengganu, Malaysia, Journal of Sustainability Science and Management, 14(6), 145-157

Maru, R. (2018), Mapping of poverty characteristics, based on the quality of fishermen's house, Bajo Tribe, South Halmahera, Indonesia. Journal of Physics: Conference Series. 1028. 1-10.

Mohd, S. M., Abdul Aziz, W. M. A., \& Wan, N. O. (2006). Analisis Kesejahteraan Hidup Nelayan Pesisir. Jurnal Kemanusian, 4(2), 58-77. 
Muhammad, R., Tibertius, N., \& Abd Aziz, M. (2015). Study of Improvement Fishermen Welfare Through Improved Productivity and Model Development in The Coastal North Konawe. The International Journal of Engineering and Science, 4(12), 62-67.

Fadhil, M. N. (2003). Penilaian Dampak Pembangunan ke Arah Kesejahteraan Masyarakat; Penilaian Dampak Sosial. Kuala Lumpur: Utusan Publication \& Distributor.

Nor, H. S. (2010). Keluar Dari Lingkaran Kemiskinan: Mobiliti Sosial di Kalangan Komuniti Pesisir Pantai, Kuala Terengganu. Unpublished thesis dissertation, Universiti Utara Malaysia.

Norizan, A. G., Mohamad, A. R., Fadzli, A., Burhanudin, A., Yendo, A., \& Aisyah, D. H. M. A. (2017). Quality of Life (QoL) of Fishermen in the West Coast States of Peninsular Malaysia. International Journal of Academic Research in Business and Social Sciences, 7(4), 313-330

Putrawan, M., \& Ananda, R. (2019). Validating Fishermen's Quality of Life Construct Validity. International Journal of Recent Technology, 8(IC2), 551-552.

Renwick, R. (2006). The quality life model. http://www.utoronto.ca/qol/concepts

Rusdiana, A., Sanuri., Muhammad, S., \& Mulyawan, S. (2020). The Relationship Between Socioeconomic Status and Consumption Pattern of Fishermen Household in Indonesia. Asian Journal of Agriculture and Rural Development, 10(1), 141-148.

Samir, M. A., \& Sara, S. M. S. (2012). Pembasmian Kemiskinan di Malaysia: Keperluan Kemahiran Pekerja Komuniti (Poverty Eradication in Malaysia: The Needs for Skilled Community Worker), Akademika, 82(1), 81-89.

Subramanian, A., \& Karuppusamy, R. (2017). Income and Expenditure Pattern and Its Impact on Socio-economic Status of Fishermen in Karaikal Region. International Journal of Development Research, 7(9), 15079-15082.

Unit Perancang Ekonomi. (1999). Usaha ke Arah Peningkatan Kualiti Hidup, Kualiti hidup Malaysia 1999. Jabatan Perdana Menteri Malaysia, Kuala Lumpur: Percetakan Nasional Berhad.

Wekkea, I. S., \& Cahaya, A. (2005) Fishermen Poverty and Survival Strategy: Research on Poor Households in Bone Indonesia. Procedia Economics and Finance, 26, 7- 11. 